Gut, 1978, 19, 1034-1042

\title{
Mucosal-associated bacterial flora of the intestine in patients with Crohn's disease and in a control group
}

\author{
SUSAN PEACH, M. R. LOCK ${ }^{1}$, D. KATZ, I. P. TODD, AND \\ SOAD TABAQCHALI ${ }^{2}$
}

From the Departments of Medical Microbiology, Histopathology, and Surgery, St. Bartholomew's Hospital, London

SUMMARY The bacterial flora intimately associated with the intestinal mucosa of patients with Crohn's disease has been examined and compared with the mucosal flora of a control group. Specimens were obtained at operation from patients undergoing intestinal surgery. Whole thickness intestinal sections were taken from the diseased segment and from a portion of uninvolved intestine from patients with Crohn's disease as well as from a control group. A section of each specimen was examined histologically. Twenty-two specimens of Crohn's tissue (12 ileum, 10 colon) and 46 control samples from small and large bowel were examined using strictly anaerobic bacteriological techniques in an anaerobic chamber. Organisms were grown under both aerobic and anaerobic conditions. A mucosal flora was found to exist in all the large bowel samples and in three-quarters of the small bowel samples. It was qualitatively similar in all the samples, consisting mainly of Gram positive bacteria, aerobic Gram negative rods and bacteroides. Greater numbers of bacteria were associated with colonic tissue $\left(10^{7}-10^{8}\right.$ per $\left.\mathrm{g}\right)$ than with tissue from the jejunum $\left(10^{3}-10^{4}\right.$ per $\left.\mathrm{g}\right)$. This difference was statistically significant $(\mathbf{P}<0.03)$. Samples from the terminal ileum were quantitatively intermediate between jejunum and colon. There was no statistical difference in the numbers of bacteria associated with Crohn's tissue compared with histologically normal tissue from the same patients and from the control group of patients. Among the bacterial isolates, however, Enterobacteria were more commonly associated with Crohn's tissue.

Previous bacteriological studies of the intestine of patients with Crohn's disease have concentrated on examining the contents of the intestinal lumen. These studies have revealed abnormalities in small bowel flora because the pathological changes, such as strictures and fistulae, which predispose to stasis and bacterial overgrowth frequently occur in these patients (Gorbach and Tabaqchali, 1969; Vince et al., 1972; Beeken and Kanich, 1973).

Bacteria, however, do not exist solely in the lumen; in experimental animals a specific bacterial flora intimately associated with the intestinal epithelium

\footnotetext{
${ }^{1}$ Present address: Department of Surgery, Royal Victoria Hospital, Bournemouth, Dorset.

${ }^{2}$ Address for reprint rcquests: Dr S. Tabaqchali, Department of Medical Microbiology, St. Bartholomew's Hospital, London E.C.1.
}

Received for publication 18 May 1978 has been demonstrated (Dubos et al., 1965; Savage, 1972), and there is also a possibility that a mucosal flora may exist in man (Plaut et al., 1967; Nelson and Mata, 1970). Furthermore, intramural bacteria have been reported in Crohn's disease (Aluwihare, 1971) and symptomatic improvement has been observed in patients treated with antibacterial drugs (Ursing and Kamme, 1975). This has led us to investigate the intestinal mucosal flora in patients with Crohn's disease and the present study was undertaken in order to determine the type, concentration, and distribution of the mucosal flora in Crohn's disease and to find out whether it differs from the normal.

In this paper, therefore, we report the results of a study of the bacterial flora intimately associated with the intestinal mucosa of patients with Crohn's disease, including both histologically involved and uninvolved tissue compared with that of patients in a control group who were not suffering from inflammatory bowel disease. 
Methods

INTESTINAL TISSUE

Specimens of intestinal tissue were obtained from segments of bowel removed during surgery of patients at St. Bartholomew's and St. Mark's Hospitals, London. None of the patients had received antibiotics before operation.

Full thickness specimens were taken from the intestinal wall of the resected intestine. Each specimen was divided into two portions. One portion, weighing approximately $0.5 \mathrm{~g}$, was placed in transport medium for bacteriological studies and the other was placed in formalin as a fixative for histological examination.

Specimens were obtained from various sites throughout the intestine and these are shown in Table 1. The study group of patients had active Crohn's disease and two types of specimen were obtained from them. Firstly, a specimen showing the histological changes characteristic of Crohn's disease and, secondly, from some of the patients a specimen of histologically uninvolved tissue. In addition, draining lymph nodes were obtained from five patients with Crohn's disease of the ileum.

The control group of patients had elective surgery of the intestine for reasons other than inflammatory bowel disease. Ileal specimens were obtained from patients undergoing right hemicolectomy and occasionally ileostomy for carcinoma of the colon; and specimens of colon from patients undergoing colectomy for carcinoma of colon. The control jejunal specimens were obtained from patients who had elective gastric and upper intestinal surgery. All control specimens were also examined histologically.

HISTOLOGICAL EXAMINATION

The formalin-fixed material was processed routinely to give $\mathrm{H}$ and $\mathrm{E}$ preparations of full thickness bowel wall. The specimen was regarded as showing Crohn's disease involvement if there was transmural inflammation with a perivascular distribution. Fissuring ulcers and granulomas were frequent, but not invariable. Where granulomas were present, these were non-caseating and negative for acid fast bacilli. In occasional instances the mucosa showed only submucosal involvement.

None of the lymph node specimens examined showed granulomatous changes.

Normal specimens were those in which there was no increase in chronic inflammatory cell population.

\section{BACTERIOLOGICAL EXAMINATION}

Transport and storage of specimens

Tissue specimens taken for bacteriological studies were placed in pre-weighed bottles containing $4.5 \mathrm{ml}$ glycerol transport broth (Crowther, 1971), immediately frozen in solid carbon dioxide for transport and stored at $-20^{\circ} \mathrm{C}$. All specimens were examined within a month.

ISOLATION AND ENUMERATION OF ANAEROBIC AND FACULTATIVE BACTERIA Since anaerobic bacteria dominate the lumenal flora of the human intestine, special techniques for the isolation of oxygen sensitive bacteria were employed during the present study. Specimens were processed in a flexible polyvinyl anaerobic chamber of the type described by Aranki et al. (1969). The working atmosphere consisted of $85 \%$ nitrogen, $10 \%$ hydrogen, and $5 \%$ carbon dioxide. Anaerobiosis in the chamber was maintained by circulating the atmosphere over granules of palladium D catalyst (Englehard Industries, Cindeford, Gloucester), and monitored by the use of methylene blue redox indicator.

The tissue samples were allowed to thaw in the chamber and were washed by vigorous agitation on a vortex mixer (Rotamixer, Hook and Tucker Ltd., Croydon, Surrey) in two changes of $4.5 \mathrm{ml}$ prereduced quarter strength Ringer's solution. The washings were cultured and the second wash freed the tissue specimens of lumenal bacteria. This was similar to the findings of Dubos et al. (1965) and Plaut et al. (1967). The tissue sample was then macerated to release associated bacteria by 'stomaching' for three minutes in a Colworth Stomacher 80 (A. J. Seward, London). The macerate was diluted $1 / 10$ and 1/100 times in prereduced quarter strength Ringer's solution and $100 \mu$ l of these dilutions and of the original macerate were seeded onto prereduced media.

The culture medium used was reinforced clostridial

Table 1 Specimens

\begin{tabular}{|c|c|c|c|c|c|c|}
\hline \multirow[t]{3}{*}{ Site } & \multirow{2}{*}{\multicolumn{2}{|c|}{ Control group }} & \multicolumn{4}{|l|}{ Study group } \\
\hline & & & \multicolumn{2}{|l|}{ Crohn's tissue } & \multicolumn{2}{|c|}{ Uninvolved tissue } \\
\hline & Patients (no.) & Specimens (no.) & Patients (no.) & Specimens (no.) & Patients (no.) & Specimens (no.) \\
\hline Jejunum & 3 & 4 & - & - & - & - \\
\hline Terminal ileum & 5 & 10 & 9 & 12 & 12 & 12 \\
\hline Colon & 4 & 6 & 7 & 10 & 10 & 10 \\
\hline Rectum & 2 & 2 & - & - & 2 & 2 \\
\hline
\end{tabular}


agar (Oxoid) with $1 \%$ glucose (w/v), $1 \%$ liver digest (Panmede, Paines, and Byrne, Greenford, England) and $10 \%$ defibrinated horse blood (RCMB isolation plates). The seeded isolation plates were packed into anaerobic jars containing activated Gaspak (BectonDickinson UK Ltd.) and fresh palladium catalyst. The sealed jars were removed from the chamber and incubated at $37^{\circ} \mathrm{C}$ for 48 hours. After incubation, colony counts were made and multiplied by the appropriate dilution factor to give the total number of bacteria per gram of tissue which grew anaerobically. This count included both strict anaerobes and facultative bacteria.

In order to investigate more thoroughly the kind of bacteria associated with the intestinal mucosa, 10 consecutive colonies were picked following a straight line across the diameter of an anaerobically incubated RCMB plate. These colonies were not picked in proportion to the total number on the plate. We have therefore, not attempted the complete characterisation of the mucosal flora, because to do so would involve the examination of a very large number of isolates which time did not allow. The isolates were picked from the culture of the highest dilution giving spaced colonies evenly distributed across the surface of the culture plate and therefore represent only those bacteria present in high concentrations.

\section{Detection of other bacterial groups}

Suitable dilutions of tissue macerate were taken out of the anaerobic chamber and seeded onto blood agar (Tissue Culture Services, Ltd., Slough, Bucks) and MacConkey's agar (Oxoid) for the detection and enumeration of aerobic and facultative organisms.

A portion of the macerate was subjected to heatshocking at $80^{\circ} \mathrm{C}$ for 10 minutes and seeded onto Willis and Hobbs agar (Willis and Hobbs, 1958). After incubation in a gas-pak jar a colony count provided an estimate of the number of clostridial spores in the specimen.

Crohn's tissue macerate was also cultured on Lowenstein-Jensen Slopes (Southern Group Laboratory) and pyruvic acid medium (Oxoid) which were incubated at room temperature, $30^{\circ} \mathrm{C}$ and $37^{\circ} \mathrm{C}$, in the diagnostic laboratory of St. Bartholomew's Hospital for the isolation of typical and atypical myocobacteria.

\section{Colony counts}

Colony counts were made with an electronic colony counter (Cook Instruments Ltd.). All counts were made by one person and only on plates where the number of colonies could be accurately assessedthat is, those with between 30 and 200 colonies.

With the above method, viable bacteria in concentrations of less than $10^{2} / \mathrm{g}$ tissue could not be assessed because of the initial dilutions used.

\section{Identification of isolates}

The strains of bacteria picked from the anaerobically incubated RCMB isolation plates from each of the samples were further identified. Both aerobic and

Table 2 Mucosal-associated bacteria in tissue specimens from control group of patients*

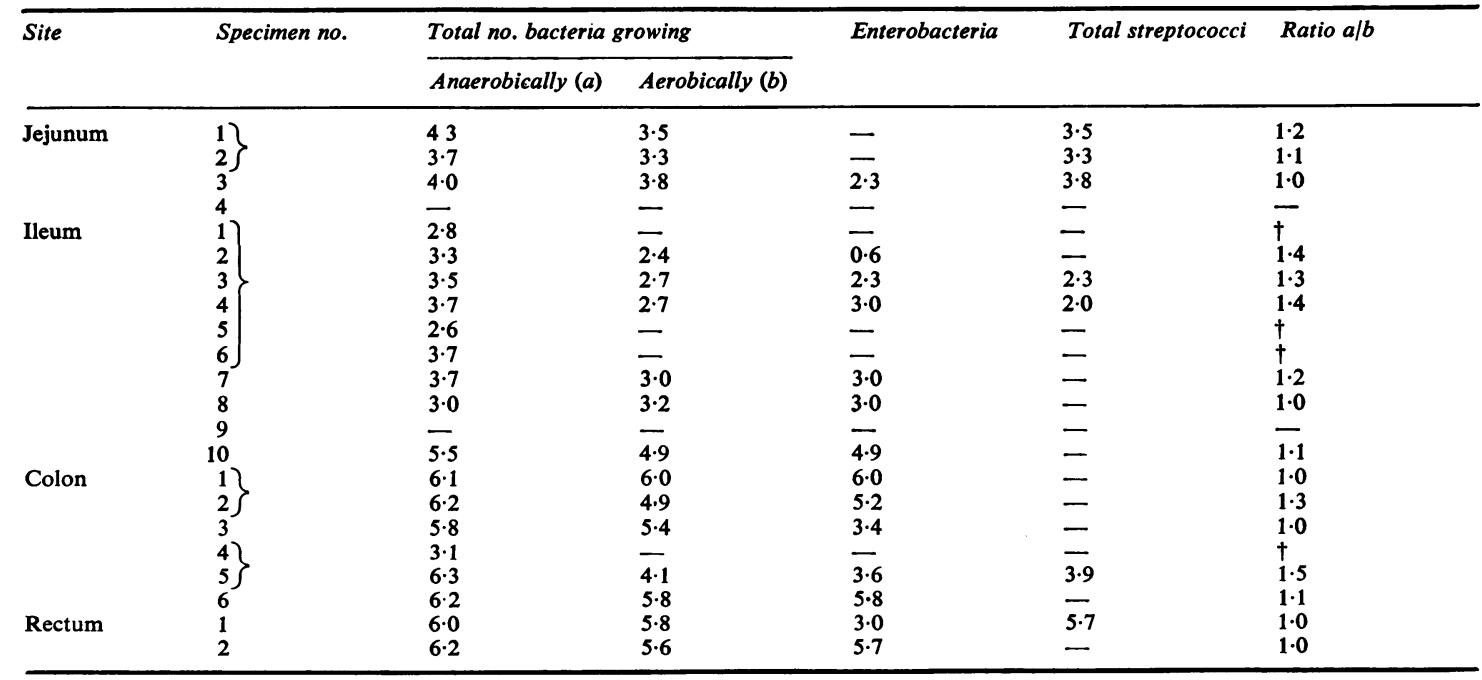

*Figures expressed as $\log { }_{10} / \mathrm{g}$ of tissue.

†Only anaerobic bacteria isolated.

-: stated group was not detected.

$\left.\begin{array}{l}1 \\ 2\end{array}\right\}$ etc.: multiple specimens from individual patients. 
anaerobic isolates were placed into broad groups according to their colonial and cellular appearance and their reaction in a Gram-stained preparation (Preston and Morrell, 1962). In addition, strictly anaerobic bacteria were assigned to genera according to the pattern of volatile fatty acids produced from glucose (Holdeman and Moore, 1972). Fatty acids were detected on a Pye Series 104 gas chromatograph under the conditions outlined elsewhere (Peach et al., 1974).

\section{Results}

\section{BACTERIAL COUNTS}

The numbers of various groups of bacteria found to be associated with intestinal tissue from the control group of patients are shown in Table 2. Similarly, the bacterial flora found to be associated with histologically normal tissue from patients with Crohn's disease is shown in Table 3 and that obtained from specimens showing histological changes characteristic of Crohn's disease is shown in Table 4. The total number of bacteria that grew under anaerobic conditions included both facultative and strictly anaerobic bacteria.

For most of the tissue specimens the number of bacteria obtained by anaerobic incubation (column (a), Tables 2-4) differed very little from that obtained by aerobic incubation (column (b), Tables $2-4)$. The ratio a:b did not generally exceed $1 \cdot 5: 1$. Thus, the mucosal flora appeared to consist mainly of facultative bacteria. There were, however, some specimens -notably from the small bowel-which, within the limitations of our method, yielded only anaerobic bacteria. Some of the facultative bacteria appeared by colonial morphology to be streptococci and most specimens yielded facultative bacteria which grew on MacConkey's agar (Enterobacteria).

The distribution of the total numbers of bacteria found to be associated with the mucosa obtained from the different sites of the gastrointestinal tract in histologically normal tissue and from Crohn's tissue is shown diagrammatically in Figs. 1 and 2. Figure 1 shows the total number of bacteria growing anaerobically and Fig. 2 those obtained on aerobic incubation only.

The numbers of bacteria per gram of tissue were highest in those specimens obtained from the distal bowel. Greater numbers of bacteria were associated with colonic specimens $\left(10^{6}-10^{7} / \mathrm{g}\right.$ of tissue) than with specimens of jejunum $\left(10^{4} / g\right.$ of tissue). This difference was statistically significant $(P<0.03)^{3}$ (Figs. 1 and 2).

There was no significant difference $(P>0 \cdot 1)^{3}$ in either numbers of bacteria or in the anaerobe to aerobe ratio, between normal tissues (Tables 2 and 3 ) and tissue showing the histological changes charac${ }^{3}$ Kruskal-Wallis one-way analysis of variance.

Table 3 Mucosal-associated bacteria in specimens of histologically uninvolved tissue from patients with Crohn's disease*

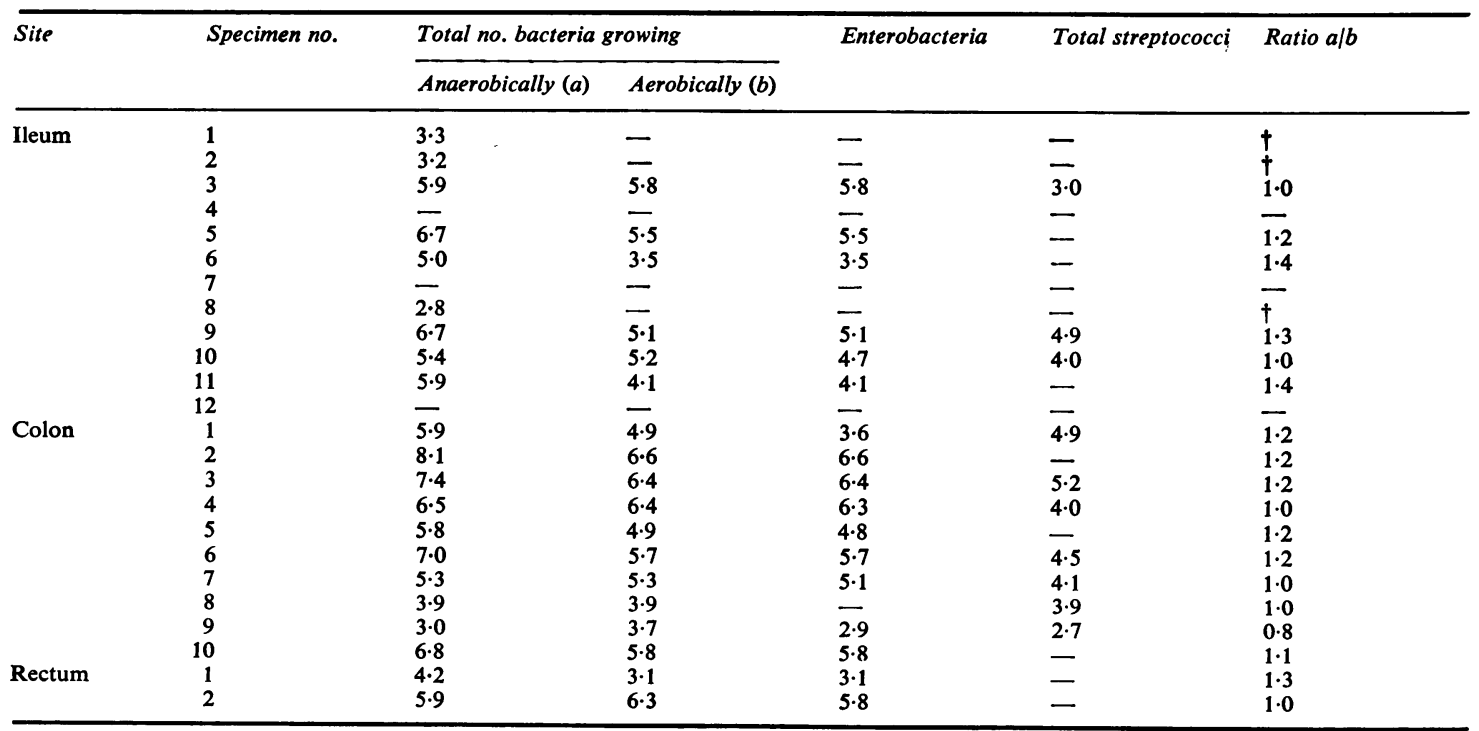

* Figures expressed as $\log 10 / \mathrm{g}$ of tissue.

†Only anaerobic bacteria isolated.

-: stated group was not detected. 
Table 4 Mucosal-associated bacteria in Crohn's tissue specimens*

\begin{tabular}{|c|c|c|c|c|c|c|}
\hline \multirow[t]{2}{*}{ Site } & \multirow[t]{2}{*}{ Specimen no. } & \multicolumn{2}{|c|}{ Total no. bacteria growing } & \multirow[t]{2}{*}{ Enterobacteria } & \multirow[t]{2}{*}{ Total streptococci } & \multirow[t]{2}{*}{ Ratio $a / b$} \\
\hline & & Anaerobically (a) & Aerobically (b) & & & \\
\hline Colon & $\left.\begin{array}{c}1 \\
2 \\
3 \\
4 \\
5 \\
6 \\
7 \\
8 \\
9 \\
10 \\
11 \\
12 \\
1 \\
2 \\
3 \\
4 \\
5 \\
6 \\
7 \\
8\end{array}\right\}$ & $\begin{array}{l}4.5 \\
3 \cdot 2 \\
6 \cdot 4 \\
- \\
5 \cdot 1 \\
6.4 \\
5 \cdot 6 \\
4 \cdot 7 \\
- \\
2.3 \\
6.3 \\
7 \cdot 4 \\
6.0 \\
6.5 \\
6.4 \\
6.6 \\
5.6 \\
4 \cdot 2 \\
3.4 \\
5.4\end{array}$ & $\begin{array}{l}4.4 \\
3.2 \\
6 \cdot 1 \\
- \\
- \\
3.5 \\
5.9 \\
5.7 \\
4 \cdot 0 \\
- \\
- \\
5.0 \\
7.6 \\
5.9 \\
6.4 \\
6.1 \\
5.5 \\
4.1 \\
2.7 \\
3.1 \\
4.3\end{array}$ & $\begin{array}{l}4 \cdot 5 \\
3 \cdot 2 \\
5 \cdot 7 \\
- \\
3 \cdot 4 \\
\overline{5} \\
5 \cdot 7 \\
3 \cdot 7 \\
- \\
- \\
5 \cdot 0 \\
7 \cdot 4 \\
5 \cdot 7 \\
6.3 \\
5 \cdot 7 \\
4.8 \\
4 \cdot 2 \\
2.4 \\
2.6 \\
4 \cdot 4\end{array}$ & $\begin{array}{l}- \\
\overline{5.8} \\
- \\
\overline{3.0} \\
5.9 \\
\overline{4.0} \\
- \\
- \\
- \\
\overline{6} \\
6.7 \\
\overline{6.0} \\
5.8 \\
5.4 \\
3.2 \\
\overline{3.0} \\
2.1\end{array}$ & $\begin{array}{l}1.0 \\
1.0 \\
1.0 \\
- \\
1.5 \\
1.0 \\
1.0 \\
1.2 \\
- \\
\dagger \\
1.3 \\
1.0 \\
1.0 \\
1.0 \\
1.0 \\
1.2 \\
1.4 \\
1.6 \\
1.1 \\
1.3\end{array}$ \\
\hline
\end{tabular}

* Figures expressed as $\log _{10} / \mathrm{g}$ of tissue.

†Only anaerobic bacteria isolated.

-: stated group was not detected.

1
2 etc.: multiple specimens from individual patients.

TOTAL NUMBER OF BACTERIA GROWING ANAEROBICALLY

LOG 10 NO.

BACTERIA/

GRAM TISSUE

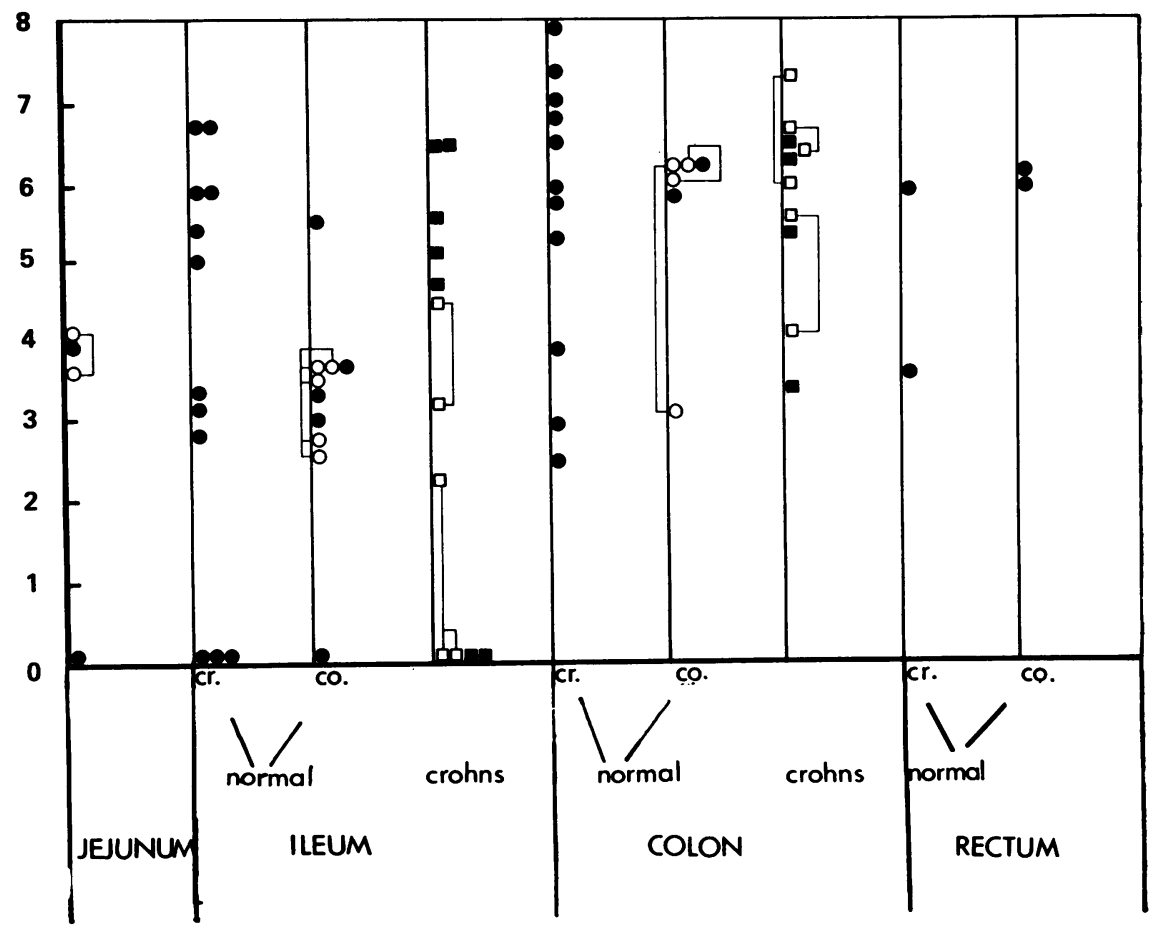

Fig. 1 Bacteria growing anaerobically.

Histologically uninvolved tissue: Cr: patients with Crohn's disease; Co: control group of patients.

Crohn's tissue. Each spot represents a single specimen. Open figures joined by a line are multiple specimens from individual patients. 
TOTAL NUMBER OF BACTERIA GROWING AEROBICALLY

LOG $_{10}$ NO. BACTERIA/ GRAM TISSUE

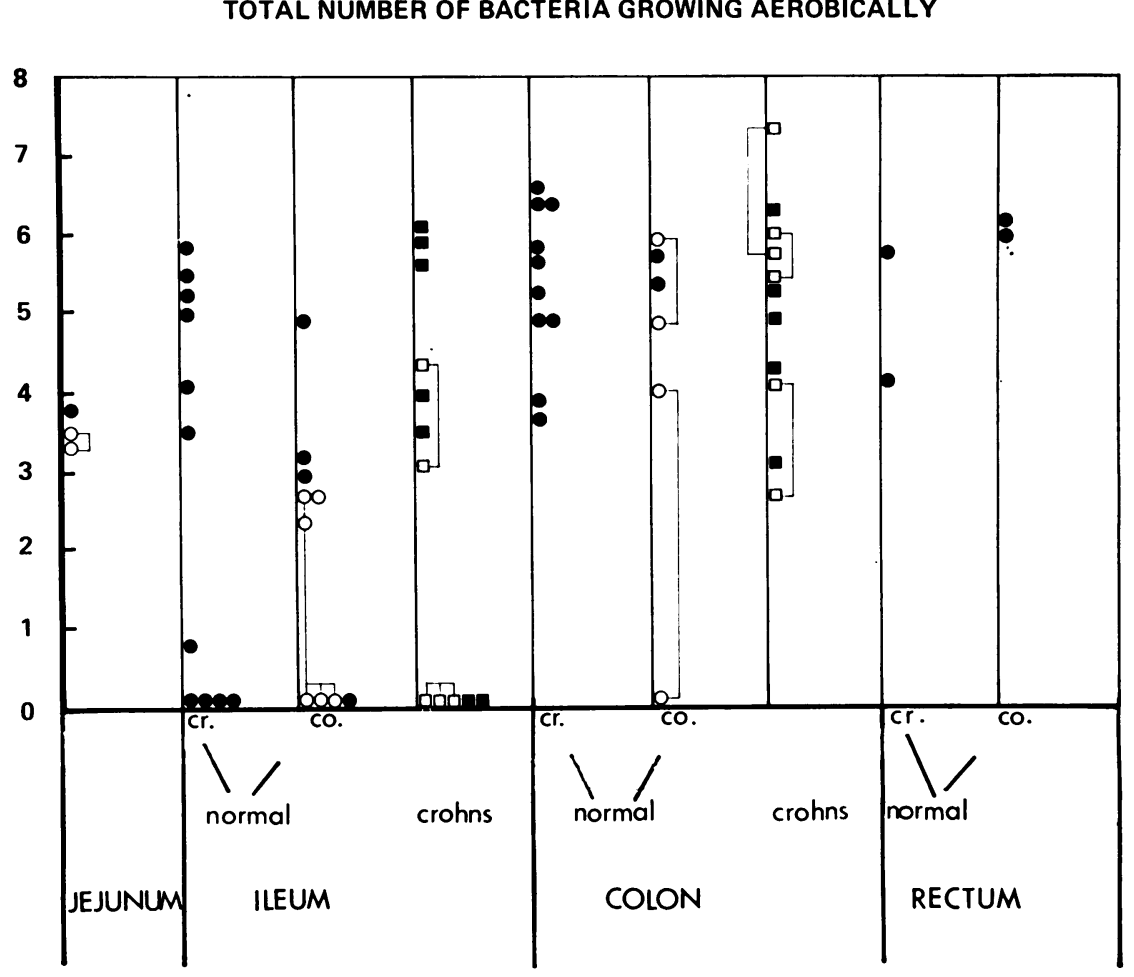

Fig. 2 Bacteria growing aerobically. Key as in Fig. 1.

teristic of Crohn's disease (Table 4).

On primary isolation plates (Willis and Hobbs agar) only four samples yielded clostridia. Three of these samples came from various levels throughout the intestine of a single patient. The fourth sample was of histologically normal colonic tissue. In all these cases about $10^{4}$ clostridia/g tissue were noted.

No Mycobacteria, typical or atypical, were isolated from any of the specimens.

There were no bacteria isolated from the five lymph nodes which were examined.

\section{TYPES OF BACTERIA}

Only 467 isolates were recovered from 62 specimens and were examined. These included both aerobic and anaerobic bacteria (Fig. 3). For all the histologically normal tissues (from both control patients and patients with Crohn's disease) about half of the strains were aerobic and half anaerobic. However. aerobic bacteria comprised three-quarters of the isolates from tissue showing changes characteristic of Crohn's disease, whether from the small bowel or the large bowel (Fig. 3).

The types of bacteria isolated were similar for all the specimens studied. Most of the aerobic isolates
(Table 5) were Gram-negative rod-shaped bacteria, but Gram positive bacteria were also common (Table 5). Gram-positive bacteria which were strictly anaerobic were also isolated (Table 6), although bacteroides were the commonest anaerobic bacteria (Table 6).

\section{Discussion}

This study has revealed a bacterial flora closely associated with the mucosa of all the specimens of colonic tissue and with most specimens of tissue from the ileum and jejunum. This bacterial flora appeared to be mainly facultative, which is in contrast to the lumenal flora, particularly in the colon where strictly anaerobic bacteria predominate (Moore and Holdeman, 1974). However, isolation plates were incubated for only two days and slowgrowing anaerobic organisms may have been missed.

Plaut et al. (1967) demonstrated the presence of a facultative bacterial flora associated with human jejunal biopsies, although not all the biopsies they studied yielded bacteria. The bacteria were mainly Gram-positive, identified as streptococci and lactobacilli. Similar findings were obtained in the present 


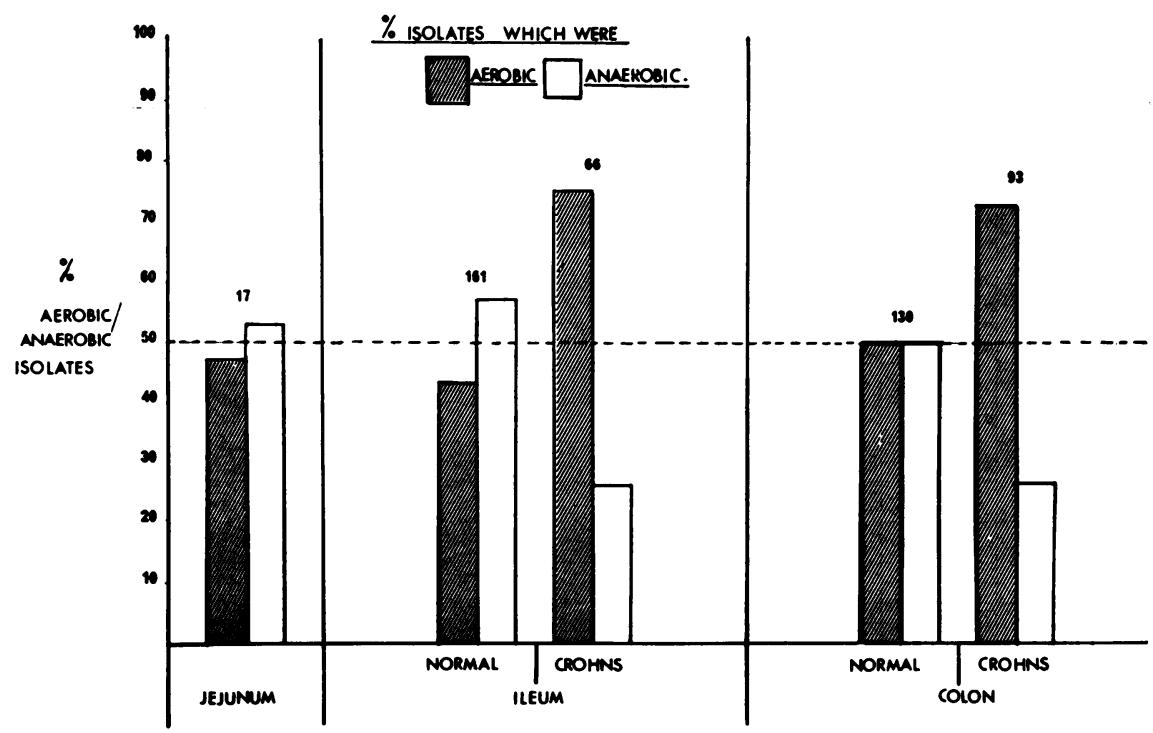

Fig. 3 Distribution of aerobic and anaerobic bacteria among the isolates. (Figures above the bars are numbers of isolates tested)

Table 5 Aerobic isolates

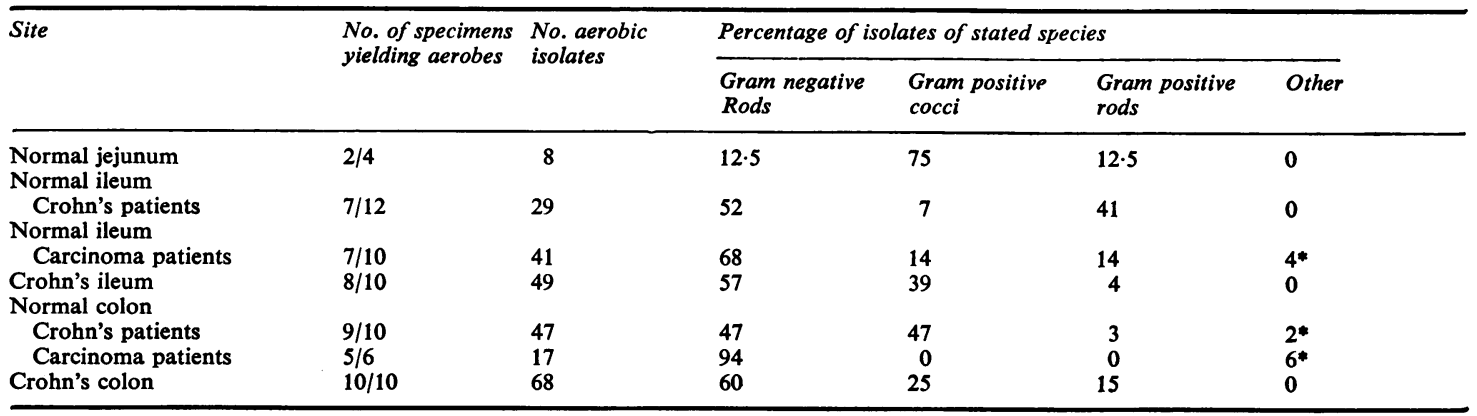

*Bacillus sp.

Table 6 Anaerobic isolates

\begin{tabular}{|c|c|c|c|c|c|c|c|c|}
\hline \multirow[t]{2}{*}{ Site } & \multirow{2}{*}{$\begin{array}{l}\text { No. of specimens } \\
\text { yielding } \\
\text { anaerobes }\end{array}$} & \multirow{2}{*}{$\begin{array}{l}\text { No. of } \\
\text { anaerobic } \\
\text { isolates }\end{array}$} & \multicolumn{5}{|c|}{ Percentage of isolates of stated species } & \multirow[b]{2}{*}{ Other } \\
\hline & & & Bacteroides & $\begin{array}{l}\text { Bifido- } \\
\text { bacteria }\end{array}$ & Clostridia & $\begin{array}{l}\text { Gram positive } \\
\text { cocci }\end{array}$ & $\begin{array}{l}\text { Gram positive } \\
\text { rods }\end{array}$ & \\
\hline $\begin{array}{l}\text { Normal jejunum } \\
\text { Normal ileum }\end{array}$ & $2 / 4$ & 9 & 78 & 11 & 0 & 11 & 0 & $\mathbf{0}$ \\
\hline Crohn's patients & $9 / 12$ & 46 & 54 & 24 & 7 & 4 & 11 & 0 \\
\hline Carcinoma patients & $8 / 10$ & 45 & 27 & 0 & 4 & 7 & 60 & $2 *$ \\
\hline Crohn's patients & $8 / 10$ & 38 & 66 & 3 & 3 & 8 & 20 & $\mathbf{0}$ \\
\hline Carcinoma patients & $6 / 6$ & 28 & 86 & 4 & 0 & 3 & 7 & $\mathbf{0}$ \\
\hline Crohn's colon & $5 / 10$ & 25 & 44 & 16 & 0 & 8 & 20 & $12 *$ \\
\hline
\end{tabular}

*Actinomyces sp.

study, although bacteroides and other faecal-type bacteria have also been demonstrated. Plaut and his colleagues reported that because of the small size of biopsy specimens they could not quantitate their results. However, a subsequent study of tissue specimens from Guatamala obtained at operation by Nelson and Mata in 1970 showed that four out of seven subjects had bacteria (mainly anaerobic streptococci) in concentrations of $10^{4}-10^{6}$ per $\mathrm{g}$ of jejunal tissue. Our own studies are in agreement with this.

There are no previous studies of the mucosal flora of the ileum. Our findings show that, within the limitations of this study, the ileal mucosal flora was 
quantitatively intermediate between that of jejunum and colon and qualitatively similar. A few ileal specimens were unusual in that they yielded only anaerobic bacteria.

All our samples of colonic tissue contained bacteria, frequently in concentrations of $10^{6}-10^{7}$ per $\mathrm{g}$ of tissue. Nelson and Mata (1970) made similar observations, but reported a 10 -fold dominance of anaerobic bacteria, which we have not found. This may be due to physiological and dietary differences in the two populations. In addition, the wide variation in numbers of bacteria that we have noted in multiple specimens from individual subjects makes it difficult to draw direct comparisons. Differences in laboratory techniques may also play a part. The specimens studies by Nelson and Mata (1970) were not washed before homogenising and processing. However, Dubos et al. (1965) and Plaut et al. (1967) found that, while bacteria could be recovered in sample washings, this action did not significantly decrease the numbers of bacteria finally cultured from intestinal tissue. What is apparent is that the mucosal flora of the human large bowel is not dominated by anaerobic bacteria to the extent found in faeces, where they outnumber aerobic bacteria by 100:1 (Moore and Holdeman, 1974).

Although the specimens included in the present study comprise the full thickness of the bowel wall, it is probable that the bacteria we describe are not intramural but colonise the layer of mucus enveloping the mucosal surface, as demonstrated histologically in the studies by Plaut et al. (1967) and Nelson and Mata (1970).

In laboratory rats and mice, mucosal association of bacteria in the gastrointestinal tract appears to be selective and certain microbial types colonise various parts of the mucosal epithelium (Schaedler et al., 1965). Thus, the villous epithelium of the ileum of rats is colonised by short rods and cocci (Savage, 1969), while anaerobic fusiform bacteria, spiral shaped bacteria, and spirochaetes are associated with the colonic mucosa (Savage, 1970). We have not found such selective colonisation in our studies of human tissues, and the same kinds of bacteria were isolated from all levels in the gastrointestinal tract.

We have found no statistical difference in the numbers and types of bacteria associated with tissue showing changes characteristic of Crohn's disease compared with histologically normal tissues (Tables 2-4).

In this study, similar groups of bacteria were represented in Crohn's tissue and the two control groups of specimens which were histologically normal. We found, however, that, among the isolates from Crohn's tissue, there appeared a greater pro- portion of aerobic bacteria. As we have examined 10 colonies per specimen and as, in this context, we are dealing with only two types of bacteria (aerobic and anaerobic), it is probable that these observed frequences are a valid estimate of the total population of bacteria (Hedges et al., 1977). No test was made for carbon-dioxide dependent organisms and, therefore, if such bacteria were present, they would be among those growing anaerobically.

Many of our aerobic isolates were Gram-negative rods. Tabaqchali et al. (1978) have shown high titres of antibodies to a large number of serotypes of $E$. coli in the serum of patients with Crohn's diesase. The presence of circulating cross-reacting antibodies to enterobacteria and colonic tissue in patients suffering from Crohn's disease and ulcerative colitis has been demonstrated (Perlmann et al., 1965; Thayer et al., 1969). Furthermore, enterobacterial antigens have been shown to have the ability to render lymphocytes cytotoxic to colonic epithelial cells (Shorter et al., 1971), suggesting that inflammatory bowel disease may be the result of a lymphocyte mediated hypersensitivity reaction to some bacterial antigens. We have not yet looked for such antigens among our isolates or at the serotypes of $E$. coli encountered, but such investigations may yield interesting results.

In order to initiate a delayed hypersensitivity reaction in the bowel wall, bacteria would have to penetrate the host defence mechanisms present at the mucosal surface and investigations along these lines are needed.

Within the limitations of the techniques available to us, we have been unable to detect any gross differences between the mucosal bacterial flora of Crohn's tissue and that of normal intestinal tissue. In future, more detailed examination of the types of bacteria associated with Crohn's tissue may prove fruitful and for such purposes it will be necessary to examine a large number of isolates from each specimen.

We are extremely grateful to the Joint Research Board of St. Bartholomew's Hospital for their financial support and wish to thank Miss Monica Leighton for the statistical analysis.

\section{References}

Aluwihare, A. P. R. (1971). Electron microscopy in Crohn's disease. Gut, 12, 509-518.

Aranki, A., Syed, S., A., Kenney E. B., and Freter, R. (1969). Isolation of anaerobic bacteria from human gingiva and mouse cacum by means of a simplified glove-box procedure. Applied Microbiology, 17, 568-76.

Beeken, W. L., and Kanich, R. E. (1973). Microbial flora of the upper small bowel in Crohn's disease. Gastroenterology, 65, 390-397.

Crowther, J. S. (1971). Transport and storage of faeces for bacteriological examination. Journal of Applied Bacteri- 
ology, 34, 477,483.

Dubos, R., Schaedler, R. W., Costello, R., and Hoet, P. (1965). Indigenous, normal and autochthonous flora of the gastrointestinal tract. Journal of Experimental Medicine, $122,67-76$.

Gorbach, S. L., and Tabaqchali, S. (1969). Bacteria, bile, and, the small bowel. Gut, 10, 693,972.

Hedges, A. J., Howe, K., and Linton, A. H. (1977). Statistical considerations in the sampling of Escherichia coli from intestinal sources for serotyping. Journal of Applied Bacteriology, 43, 271-280.

Holdeman, L. V., and Moore, W. E. C. (1972). Anaerobe Laboratory Manual. Virginia Polytechnic Anaerobe Laboratory: Blacksburg, Virginia.

Moore, W. E. C., and Holdeman, L. V. (1974). Human fecal flora: the normal flora of 20 Japanese-Hawaiians. Applied Microbiology, 27, 961-979.

Nelson, D. P., and Mata, L. J. (1970). Bacterial flora associated with the human gastrointestinal mucosa. Gastroenterology, 58, 56-61.

Peach, S., Fernandez, F., Johnson, K., and Drasar, B. S. (1974). The non-sporing anaerobic bacteria in human faeces. Journal of Medical Microbiology, 7, 213-221.

Perlmann, P., Hammarström, S., Lagercrantz, R., and Gustafsson, B. E. (1965). Antigen from colon of germfree rats and antibodies in human ulcerative colitis. Annals of the New York Academy of Science, 124, 377-394.

Plaut, A. G., Gorbach, S. L., Nahas, L., Weinstein, L., Spanknebel, G., and Levitan, R. (1967). Studies of Intestinal microflora. III. The microbial flora of human small intestinal mucosa and fluids. Gastroenterology, 53, 868-873.

Preston, N. W., and Morrell, A. (1962). Reproducible results with the Gram stain. Journal of Pathology and Bacteriology, 84, 241-243.

Savage, D. C. (1969). Localization of certain indigenous micro-organisms on the ileal villi of rats. Journal of
Bacteriology, 97, 1505-1506.

Savage, D. C. (1970). Associations of indigeous microorganisms with gastrointestinal mucosal epithelia. American Journal of Clinical Nutrition, 23, 1495-1501.

Savage, D. C. (1972). Survival on mucosal epithelia, epithelial penetration and growth in tissue of pathogenic bacteria. Symposium of the Society for General Microbiology 22, 25-56.

Schaedler, R. W., Dubos, R. J., and Costello, R. (1965). Association of germ-free mice with bacteria isolated from normal mice. Journal of Experimental Medicine 122, 77-82.

Shorter, R. G., Huizenga, K. A., Spencer, R. J., Aas, J., and Guy, S. K. (1977). Inflammatory bowel disease: cytophilic antibody and the cytotoxicity of lymphocytes for colonic cells in vitro. American Journal of Digestive Diseases, 16, 673-680.

Tabaqchali, S., O'Donoghue, D. P., and Bettelheim, K. A. (1978). Escherichia coli antibodies in patients with inflammatory bowel diseases. Gut, 19, 108-113.

Thayer, W. R., Jr., Brown, M., Sangree, M. H., Katz, J., and Hersh, T. (1969). Escherichia coli 0:14 and colon hemagglutinating antibodies in inflammatory bowel disease. Gastroenterology, 57, 311-318.

Ursing, B., and Kamme, C.'(1975). Metronidazole for Crohn's disease. Lancet, 1, 775-777.

Vince, A., Dyer, N. H., O'Grady, F. W., and Dawson, A. M. (1972). Bacteriological studies in Crohn's disease. Journal of Medical Microbiology, 5, 219-229.

Whorwell, P. J., Phillips, C. A., Beeken, W. L., Little, P K., and Roessner, K. D. (1977). Isolation of reovirus-like agents from patients with Crohn's disease. Lancet, 1, 1169-1171.

Willis, A. T., and Hobbs, G. (1958). A medium for the identification of clostridia producing opalescence in egg-yolk emulsions. Journal of Pathology and Bacteriology, 75, 299-305. 